\title{
Regulation and the circulation of knowledge: Penicillin patents in Spain
}

\author{
Ana Romero de Pablos (*) \\ (*) Departamento de Ciencia, Tecnología y Sociedad, IFS-CCHS, CSIC, Madrid. \\ ana.romero@cchs.csic.es
}

Dynamis

[0211-9536] 2011; 31 (2): 363-383
Fecha de recepción: 30 de diciembre de 2010

Fecha de aceptación: 3 de febrero de 2011

SUMMARY: 1.-Introduction. 2.-Patents' archives as sources for historical reconstruction. 3.-The Spanish dictatorship and the autarchy. 4.- Patents as regulators. 5.-Foreign competition. 6.- Regulation and the circulation of knowledge. 7.-Conclusions: liability and predictability.

ABSTRACT: This paper tells the early history of penicillin patenting in Spain. Patents turn out to be useful instruments for analysing the management of knowledge and its circulation in different professional and geographical domains. They protected knowledge while contributing to standardisation. Patents also ensured quality and guaranteed reliability in manufacturing, delivering and prescribing new drugs. They gained special prominence by allowing the creation of a network in which political, economic and business, industrial power, public health and international cooperation fields came together. The main source of information used for this purpose has been the earliest patent applications for penicillin in Spain between 1948 and 1950, which are kept in the Historical Archives of the Oficina Española de Patentes y Marcas. The study of these patents for penicillin shows their role as agents in introducing this drug in Spain.

KEY WORDS: History, antibiotics, penicillin, patents, circulation of knowledge, regulation, Spain, 1950s.

PALABRAS CLAVE: Historia, antibióticos, patentes, circulación del conocimiento, regulación, España, década de los 50.

\section{Introduction}

The aim of this paper is to contribute to the early history of penicillin in Spain. The main source of information used for this purpose has been the first patent applications for this drug in Spain between 1948 and 1950, which are kept in the Historical Archives of the Oficina Española 
de Patentes y Marcas (AHOEPM) ${ }^{1}$. This was a period in the history of antibiotics when industrial regulation began to play an important role. Knowledge of their therapeutic effectiveness against infections such as syphilis and gonorrhoea spread rapidly in the medical world and within the pharmaceutical industry. The documents studied here help understand how penicillin travelled and spread worldwide after the Second World War, and particularly in Spain.

\section{Patents' archives as sources for historical reconstruction}

The value of a patent as a documentary source is based on its role as mediator between different areas. In order to move and circulate knowledge generated in a laboratory, some accommodation and a degree of consensus among the involved agents are implied. Patents are taken here as agents that connected Spanish research to different interests of the political, economic and industrial powers. Patents and their regulation became key elements in this process. All this material, taken together, contributes to a better understanding of the practices and routines concerning the introduction of penicillin into Spain.

Historical studies on patents have focused on the repercussions of state laws, and how knowledge production gives rise, at the same time, to the institutions needed to administer it ${ }^{2}$. Other authors see patents as a tool

1. The Registro de la Propiedad Industrial (Industrial Property Registry) was a body created in 1903, dependent on the Ministry of Agriculture, Industry, Commerce and Public Works, to manage industrial property and international relations. In 1975 it became an autonomous body dependent on the Ministry of Industry, and in 1992 the Registry changed its name to Oficina Española de Patentes y Marcas, its current name. A joint project between the Oficina Española de Patentes y Marcas and the Universidad Autónoma de Madrid has allowed the index of a large proportion of the patents kept in its Historical Archives available at http:// historico.oepm.es/archivohistoricow3c/index.asp

2. Keith, S. T. Inventions, patents and commercial development from governmentally financed research in Great Britain: the origins of the National Research Development Corporation. Minerva. 1981; 19 (1): 92-122. Etzkowitz, Henry Knowledge as property: The Massachusetts Institute of Technology and the debate over academic patent policy. Minerva. 1994; 32 (4): 383-421. Mowery, David C. et al. The growth of patenting and licensing by U.S. universities: an assessment of the effects of the Bayh-Dole Act of 1980. Research Policy. 2001; 30: 99-119. Mowery, David C.; Ziedonis, Arvidis A. Academic patent quality before and after the Bayh-Dole Act in the United States. Research Policy. 2002; 31: 399-418. Metlay, Gnscha Reconsidering 
for analysing how scientific and technological knowledge is produced ${ }^{3}$, and as new actors in new interactive spaces ${ }^{4}$. Protecting new procedures for drug production came by negotiation in particular spaces where the agents involved are allowed to coexist ${ }^{5}$. New practices and dynamics were introduced by changes in the law, and had their repercussions on industry ${ }^{6}$.

There are twelve dossiers in the AHOEPM related to the first attempts by foreign companies to patent penicillin production methods in Spain, dated between 1948 and 19507.

The documents kept in the AHOEPM show that between 1948 and 1950 three companies applied for a patent in Spain in relation to the methods, procedures and instruments related to the manufacture of penicillin. Of them, there are four dossiers between 1948 and 1949 in the registry office that processed applications.

In addition to the files preserved at the Oficina Española de Patentes $y$ Marcas (OEPM), the Boletin Oficial de la Propiedad Industrial has also been consulted $^{8}$. On a fortnightly basis, this publication documents and registers all the vicissitudes of applications from the beginning of the procedure. This material allows patents to be followed on their path to approval, along which, in most cases, a set of circumstances altered, interrupted and even aborted the procedure.

renormalization: stability and change in 20th-century views on university patents. Social Studies of Science. 2006; 36 (4): 565-597.

3. Romero de Pablos, Ana. Gobernanza y gestión del conocimiento: las patentes, un instrumento de estudio. Arbor. 2005; 715: 333-350.

4. Slinn, Judy. Patents and the UK pharmaceutical industry between 1945 and the 1970s. History and Technology. 2008; 24 (2): 191-205.

5. Gaudillière, Jean-Paul. Professional or industrial order? Patents, biological drugs, and pharmaceutical capitalism in early twentieth century Germany. History and Technology. 2008; 24 (2): 107-133.

6. Cassier, Maurice. Patents and public health in France. Pharmaceutical patent law in-the-making at the patent office between the two world wars. History and Technology. 2008; 24 (2): 135151.

7. Patents 184673, 187178, 187313, 187312, 187371, 187378, 188188, 188260, 190142, 190143, 193056, 194256.

8. The Boletín Oficial de la Propiedad Intelectual e Industrial was created by Royal Decree on 2 August 1886, in accordance with the Paris Convention for the protection of industrial property. At the beginning of the 20th century it was renamed Boletin de la Propiedad Industrial [Spanish Official Industrial Property Gazette]. The Gazettes consulted relate to the years 1948-1950. Information regarding the patents studied was found in Gazette numbers 1487 , $1488,1490,1491,1492,1494,1495,1496$, and 1502. OEPM, Madrid. 
Several documents held at the General Archive of the Ministry of Foreign Affairs (AGMAE) and those from patents archives include archival material from the health political authorities. The whole set contributes to the reconstruction of the early history of penicillin in which technical details and diplomatic issues played a significant part $^{9}$.

\section{The Spanish dictatorship and the autarchy}

This paper rests on recent historiography of both antibiotics and patents. Those on the Spanish pharmaceutical industry show the impact of nationalisation of German industries after the Second World War, and the leading role played by antibiotics in an industrial project in which banks, industrialists and scientific research responded differently to autarchic practices. Early circulation of antibiotics in Spain in the mid-1940s included clinical and academic settings as well as the public propaganda displayed by the Spanish political authorities ${ }^{10}$. Political and economic history focusing on the early Franco years has answered and put into context many of the questions raised, which are often only hinted at by the documents ${ }^{11}$.

The first attempt to patent penicillin in Spain was in 1948. At least since 1944, Spanish doctors and chemists knew about this drug and its therapeutic properties against infections. A clinical therapeutic space was opening up, according to the reports published by Spanish doctors. The new drug also entered the agenda of public health policy. There were three

9. Note verbale sent by the Ministry of Foreign Affairs to the Embassy of the United States of America in Madrid, 15 Jun 1945. AGMAE, Madrid. R/002246/1.

10. Puig Raposo, Nuria. La nacionalización de la industria farmacéutica en España: el caso de las empresas alemanas, 1914-1970. Madrid: Fundación Empresa Pública; 2001, WP 2001/2. Santesmases, María Jesús. Antibióticos en la autarquía: banca privada, industria farmacéutica, investigación científica y cultura liberal en España, 1940-1960. Madrid: Fundación Empresa Pública; 1999, WP 9906. Santesmases, María Jesús. Distributing penicillin: the clinic, the hero and industrial production in Spain, 1943-1952. In: Quirke, Viviane; Slinn, Judy, eds. Perspectives on twentieth-Century pharmaceuticals. Oxford: Peter Lang; 2010, p. 91-118.

11. Portero, Florentino. Franco aislado. La cuestión española (1945-1950). Madrid: Aguilar; 1989; Lleonart, Alberto J.; Castiella y Maiz, Fernando. España y la ONU: la cuestión española. Madrid: CSIC; vol. I 1978, vol. II 1983, vol. III 1985, vol. IV 1991, vol. V 1996, vol. VI 2002. Catalán, Jordi. La economía española y la segunda guerra mundial. Barcelona: Ariel Historia; 1995. Nadal, Jordi; Catalán, Jordi, eds. La cara oculta de la industrialización española. Madrid: Alianza Universidad; 1994. 
key figures in this process: doctors Carlos Jiménez Díaz and his disciple Eduardo Ortiz de Landázuri, and the chemist Florencio Bustinza. Jiménez Díaz and Ortiz de Landázuri played a key role in the Commission for Penicillin Distribution in Spain which began working at the end of 1944 to oversee and control the import and distribution of this product. Bustinza played a significant part in popularising the discovery. The trips Bustinza made to the United States between 1945 and 1946 and his visits to different penicillin manufacturing plants including Merck, which as we shall see later was one of the first companies to introduce its patents in Spain- and to London, where he visited Alexander Fleming, provided him the authority to write journal articles, books and conference papers praising the benefits of the new drug for different audiences ${ }^{12}$.

The 1940s, when penicillin began to circulate in Spain, were remarkable for the political isolation of Spain. Franco had come to power after the Spanish Civil War (1936-1939), helped by Italy and Germany, and during the Second World War supported the Axis powers. This affected Spain's relationship with its political and geographical neighbours. In 1946, the General Assembly of the United Nations vetoed Spain's membership in international organizations, and Spain was not accepted until November 1950. The end of the Second World War and, slightly later, of Spanish political isolation made penicillin an additional agent in the shift of Franco's public policies regarding industry and medical care.

It may well be that both the information about this new drug and the work of the Commission for Penicillin Distribution that distributed the small amounts of penicillin being bought by the Spanish authorities by the mid-1940s led the Spanish authorities to rethink their early policy of not promoting the production of penicillin in Spain. By the mid-1940s, the main policy regarding penicillin was limiting the entry of all products from abroad, including penicillin. However, the creation of the Commission could be regarded as recognition of the social and medical demand for penicillin.

It was in 1945 when the political authorities believed «the moment had come» (sic) to pay attention to penicillin manufacturing, abandon limited imports and promote the production of penicillin in Spain. With this aim, the ministry of Foreign Affairs addressed the US and British Embassies requesting permission for Spanish technical personnel to visit

12. Santesmases, 2010, n. 10. 
penicillin production plants and learn about the manufacturing of the drug in both countries ${ }^{13}$. The response of the British Foreign Office was just an acknowledgement of the reception of the request ${ }^{14}$. That of the US Embassy was clear and disappointing:

«[I]n view of the [Spanish] General Health Board's previous policy, of forbidding the import of several American pharmaceutical specialties, without taking the price, quality and real need into consideration, the Embassy cannot request that American penicillin manufacturers reveal their elaboration methods and techniques to the Spanish health authorities if, as a result of doing so, the General Health Board opposes importing the American product into Spain in the future» ${ }^{15}$.

This answer from the US Embassy in Madrid confirmed Spain's isolation in the 1940s and early 1950s, as well as its tense relationship with the United States and other European countries ${ }^{16}$. Even if, as the ministry note verbale to the Embassies stated, it was «extremely important for the Spanish Government to obtain the necessary permission from the American Government for Spanish technical personnel to visit the production and manufacturing centres in the USA where it is produced», the Embassy maintained the role of protecting US drug industry interests. The answer raised no doubts of American dissatisfaction in regard to Spanish autarchy, marked by the protection of national production and limitation of foreign trade. They argued that there was enough production of penicillin in the US to fill Spanish needs and that the price was low. A complaint regarding

13. «The Ministry of Foreign Affairs has the pleasure of greeting the Embassy of the USA in this capital and has the honour of informing you that, the hostilities in Europe having ended, the Spanish health authorities believe the time has come for Spain to manufacture penicillin to meet this country's medical needs. With this aim, it is extremely important for the Spanish Government to obtain the necessary permission from the American Government for Spanish technical personnel to visit the production and manufacturing centres in the USA where it is produced, as this country can guarantee that its elaboration procedures are carried out with the greatest care. If permission is granted, your embassy would be provided with names of the people that the Spanish health authorities would entrust with carrying out the relevant studies». Note verbale sent by the Ministry of Foreign Affairs to the Embassy of the United States of America in Madrid. 15 Jun 1945. AGMAE, Madrid. R/002246/1.

14. This document, dated 22 Jun 1945, is a simple acknowledgement of receipt. AGMAE, Madrid. R/002246/1.

15. Note verbale sent by the Embassy of the United States of America to the Ministry of Foreign Affairs. 29 Jun 1945. AGMAE, Madrid. R/002246/1.

16. On the Spanish foreign affaires, see Portero, n. 11; Lleonart; Castiella y Maiz, n. 11. 
forbidding imports of pharmaceuticals from the US was also included in the US Embassy's answer to this request ${ }^{17}$.

This rapid reaction by the US Embassy to protect knowledge generated by the US for obtaining penicillin was the US official position toward the dictatorship, which included Spanish industrial policy and the restrictions imposed on imports by industrial legislation during the early years of the Franco regime, to the subsequent detriment of foreign companies ${ }^{18}$. This strong protectionism that kept out imports not only did not strengthen Spanish industry, but isolated it even more ${ }^{19}$ and, at the same time, created the basis for the strong development of imports from the end of the autarchic period onwards ${ }^{20}$.

As a result of Franco's support to the Axis powers, the diplomatic relationship of Spain with the United States and Europe - mainly the United Kingdom and France was marked by their opposition to the his regime. All

17. The whole text of the answer deserves a reading: «The Embassy of the USA has pleasure in greeting the Ministry of Foreign Affairs and is pleased to acknowledge receipt of note verbale no 509, of 15 June last, in which the Spanish health authorities stated that they believed the time had come for penicillin to be manufactured in Spain to meet the country's needs. In keeping with this idea, the Note from your Department expressed an interest in sending a group of technical personnel to the USA to visit the production centres and study elaboration methods. This embassy would like to point out that the USA has — for some time- had sufficient penicillin available to meet all Spain's needs had the Spanish authorities wished to import the quantities necessary to meet those requirements. In addition, the price (95 cents per ampoule for 100,000 Oxford units) is very low as a result of the USA's enormous production. Therefore neither the quantities required nor the price can be considered obstacles for importing penicillin. The Embassy's Consular Section is willing to provide the visas for the technical personnel that the Spanish Government wishes to send to the USA. However, in view of the General Health Board's previous policy, of forbidding the import of several American pharmaceutical specialties, without taking the price, quality and real need into consideration, the Embassy cannot request that American penicillin manufacturers reveal their elaboration methods and techniques to the Spanish health authorities if, as a result of doing so, the General Health Board opposes importing the American product into Spain in the future». Note verbale sent by the Embassy of the United States of America to the Ministry of Foreign Affairs. 29 June 1945. AGMAE, Madrid. R/002246/1. The fact that there is no document listing the technical staff to whom the Spanish health authorities entrusted this task suggests that, given the response of the American authorities, it was never sent.

18. Nadal; Catalán, n. 11.

19. Puig Raposo, Nuria. Redes empresariales de oportunidad en la España del siglo XX: el caso de la industria químico-farmacéutica. Historia Empresarial ICE. 2004; 812: 179-188.

20. Cebrián, Mar; López, Santiago. Economic growth, technology transfer and convergence in Spain, 1960-73. In: Ljungberg, Jonas; Smits, Jan Pieter, eds. Technology and human capital in historical perspective. New York: Palgrave McMillan; 2004. 
of them, the USA, Great Britain and France, had tried to protect commercial relationships affected by the foreign trade policies of the early Franco period that restricted the granting of import licences ${ }^{21}$.

In September 1946, the Dirección General de Sanidad (DirectorateGeneral for Health) reported to the Ministry of Industry that manufacturing penicillin in Spain would have many benefits. The reasoning used was the high consumption of penicillin and therefore its high cost, which exceeded the $\$ 5,000 /$ month allocated for importing it ${ }^{22}$. This situation suggests that industrial policy authorities, the pharmaceutical industry, and the banks should come to an agreement.

In the middle of this process and barely two years after welcoming Florencio Bustinza in London, Alexander Fleming visited Spain in May 1948. Welcomed as a hero, his trip through Madrid, Barcelona and other Spanish cities not only represented a step forward in the process of reinforcing the arguments in favour of producing penicillin in Spain, but was also used by the Franco dictatorship as propaganda to strengthen the State and its policies. The three years which elapsed between the complaints by the representatives of the American Embassy about the boycott on importing their products into Spain and the first document applications for penicillin manufacturing patents by foreign companies were productive. In September 1948 the Boletin Oficial del Estado published a Decree that was a call for proposals for two penicillin factories to manufacture the drug in Spain. The decree declared the manufacture of penicillin to be of National interest, which meant some protections from the State to the producers regarding prices and currency to pay royalties ${ }^{23}$.

Agreement between those responsible for industrial policy, the pharmaceutical industry and the banks was finally possible. Two proposals applied and were successfully granted permission to manufacture penicillin

21. Nadal; Catalán, n. 11.

22. Santesmases, 2010, n. 10.

23. Santesmases, 2010, n. 10. Images from NoDo which show Fleming's visit to Spain: 283 A Year VI, 284 B Year VI, 637 B Year XIII. Filmoteca Española. Archive, Madrid. On the history of the NoDo, see Tranche, Rafael; Sánchez-Biosca, Vicente. NO-DO. El tiempo y la memoria. Madrid: Cátedra/Filmoteca Española; 2002. On sciences and the NoDo, see Ordóñez, Javier; Ramírez, Felipe E. Los públicos de la ciencia española: un estudio del NO-DO. In: Romero de Pablos, Ana; Santesmases, María Jesús, eds. Cien años de política científica en España. Madrid: Fundación BBVA; 2008, p. 257-292. Decree of 1 Sep 1948, which declares the manufacture of penicillin to be of «national interest» and issues a public call for bids for Spanish companies to carry it out. Published in the Boletín Oficial del Estado, 6 Oct 1948. 
in Spain. A group of entrepreneurs and bankers, who belonged to the professional liberal elite and had a different culture from that of the official political class, was one of the applicants ${ }^{24}$. The patent opened a common space where doctors, industrialists, politicians and bankers came together ${ }^{25}$.

\section{Patents as regulators}

The law in force at the end of the 1940s was the Estatuto de la Propiedad Industrial (Industrial Property Statute) of 26 July 1929. This Royal decree-law was a reform of the Ley de Propiedad Industrial of 1902 and its Regulations of 1924. The Statute was amended by successive decrees, in 1930 and in 1931. The latter decree, Estatuto de la Propiedad Industrial became law later the same year in the Ley de la República ${ }^{26}$. This Statute remained in force more than 50 years, until 1986, when the current Patents Law was enacted $^{27}$.

The first article of the chapter covering patents in the by-laws of 1931 describes, in a similar way to the law of other countries, the definition and function of patents. However, the Spanish patent law made a distinction between an invention patent and an introduction patent ${ }^{28}$.

24. Santesmases, 1999, n. 10.

25. Tanner, Jacob. Standards, market and modernity. In: Masutti, Christophe; Bonah, Christian; Rasmussen, Anne; Simon, Jonathan, eds. Harmonizing drugs. Standards in 20th-century pharmaceutical history. Paris: Editions Glyphe; 2009, p. 45-60.

26. For historical legislation on industrial property in Spain, see Sáiz, J. Patricio, Legislación histórica sobre propiedad industrial: España (1759-1929). Madrid: Oficina Española de Patentes y Marcas; 1996.

27. Patents Law. Law 11/1986 of 20 March. Published in the Boletín Oficial del Estado on 26 Mar 1986.

28. Article 45 of the Statute states: «a patent is understood as the certificate granted by the State which acknowledges the right to the exclusive use of an invention in industry and to provide, trade or sell the objects manufactured as a result of that invention for a fixed period of time. Patents can be for an invention, or for introduction, also called exploitation.

Invention patents give the licensee the exclusive right to manufacture, use or produce, sell or use the object of the patent as an industrial and lucrative exploitation in the conditions determined in this statute.

Introduction patents confer the right to manufacture, use or produce and sell what is made in the country, but they do not give the right to prevent others from introducing similar objects abroad, subject to the restrictions of the national production protection laws». 
An invention patent was, and still is, the traditional form that is internationally understood as a patent: it grants monopolistic protection for 20 years for any invention that is new, useful and has an industrial application. The application for it must contain a sufficiently clear description for an expert on the subject to reproduce its content and apply it. This type of patent grants the applicant the exclusive right to manufacture, distribute or produce, sell or use the object of the patent industrially and for profit in the conditions determined by law.

The introduction patent was granted for a ten year period and, although it also granted the right to manufacture, use or produce, and sell what was made in the country, it did not grant the right to prevent others from introducing similar objects abroad. The introduction patent suggests an institutional acknowledgement of the Spanish situation on the technological front: Spain needed help for the entry of foreign inventions. This was the case of one of the Spanish penicillin patents granted, as will be seen below.

The wording of the articles on invention and introduction suggests that the aim of the authorities responsible for regulation was to provide a guarantee, and to ensure the reliability of the innovation covered by the patent and the product patented. This guarantee was subject to and regulated by rules. The need for a guarantee and reliability were arguments used to justify the regulation of the production and distribution of diphtheria serum in Germany and France at the beginning of the twentieth century. As it was not possible to patent a drug, but the methods to manufacturing it could be patented, it was necessary to find other forms of regulation and control that would allow the drug to circulate ${ }^{29}$. In Spain, as shown below, the introduction of the penicillin patent opened up a new space where Franco's industrial policy offered the possibility for private firms

«Article 68. An invention which has been disclosed or patented abroad can be the object of a patent if it has not been put into practice or implemented in Spain ...

Article 69. An application for an introduction patent is subject to the same requirements and conditions as the invention patent, and will be subject to the same formalities.

Article 70. The applicant for an introduction patent must indicate in the application the number, date and origin of the foreign patent, or provide the necessary source of information if s/he does not have that information».

29. Simon, Jonathan; Hüntelmann, Axel C. Two models for production and regulation: the diphtheria serum in Germany and France. In: Quirke, Viviane; Slinn, Judy, eds. Perspectives on twentieth-century pharmaceuticals. Oxford: Peter Lang; 2010, p. 37-62. 
to collaborate with the dictatorship - to favour penicillin production in Spain - that would produce benefits for the private firms.

\section{Foreign competition}

The first foreign company to file a patent application was the Danish company Lovens Kemische Fabrik Ved A. Kongsted (hereafter Lovens), in July $1948^{30}$. No Spanish company purchased any of their patents and therefore they were not exploited.

Lovens was previously in touch with Spanish chemists and industry representatives. The first time the company showed interest in setting up a penicillin plant dates back to 1947. The document signed by the company Leopenicilina is dated in Bilbao, June 1947 and was addressed to the Ministry of Industry. It was sent to the Instituto Nacional de Industria (INI) for assessment. The proposal for installing a plant in Navarre, in the North of Spain, to produce penicillin under a licence from this Danish patent was greatly welcomed by the INI administrators who could already see that penicillin was a necessary product with extensive medical applications and a foreseeably large market in the future. This report also makes clear that the Spanish administrators knew there were representatives of the American companies in Spain (they mention the company Abbot of Chicago), companies that had already showed their competence in producing penicillin. All these contacts show the interest of foreign industry in the Spanish market, an interest that alerted the Spanish authorities ${ }^{31}$. Lovens proposal did appear to be part of the company's expansion policy. The same path had been

30. There are four dossiers between 1948 and 1949 in the registry office that processed applications. All of them were granted in a very short space of time -in some cases the process took only one day - although they did not succeed in obtaining a license: Patent number 184673: A method of recovering a purified salt from penicillin. Applied for on 22/07/1948 and granted on 02/02/1949. Patent number 187178: A method for recovering a penicillin salt. Certificate of addition (patent number 184613); applied for on 23/02/1949 and granted on 24/02/1949. Patent number 188188: A procedure for producing penicillin salts. Applied for on 12/05/1949 and granted on 13/05/1949. Patent number 188260: A method for producing penicillin and penicillin salts. Applied for on 18/05/1949 and granted on 19/05/1949. AHOEPM, Madrid

31. Santesmases, 1999, n. 10. The INI was the body that directed industrial policy in the Franco period. Martín Aceña, Pablo; Comín, Francisco. INI. 50 años de industrialización en España. Madrid: Espasa Calpe; 1991. 
followed by this Danish firm in Italy. In 1947, the Italian company Leo built a plant in Rome to produce penicillin, which started working in 1947 with the support of technicians and scientists from Lovens and their patent ${ }^{32}$.

At the beginning of 1949, Antonio Gallego, professor of Physiology of the Faculty of Medicine at the University of Madrid, travelled as a representative of the Banco Urquijo to the Merck plant (Rahway, New Jersey). The agreement signed on 14 January 1949 considered establishing a penicillin plant in Spain. The agreement was a path toward the submission of an application by the Urquijo Bank for one of the two factories that the government would approve, as was stated in the Ministry of Industry call of $1948^{33}$.

Merck \& Co. Inc. was the second foreign firm to submit an application for the introduction of a patent related to penicillin in Spain, and did so in March 1949. Between March and June that year, the four Merck patent applications for producing penicillin were approved by the Registro de la Propiedad Industrial (Industrial Property Registry). All of them were invention patents except for patent number one, entitled, «A procedure for penicillin production», which was an introduction patent ${ }^{34}$.

At the end of 1949, the US firm Schenley Industries, Inc. also applied. It submitted four applications and one was approved: «A method for the production of penicillin sodium». The novelty of Schenley's patents was that, while Merck and Lovens always tried to protect procedures and methods,

32. See Capocci in this volume.

33. On Banco Urquijo and its support for industry and research see Santesmases, n. 10, 1999. Also see Santesmases, María Jesús. Entre Cajal y Ochoa. Ciencias biomédicas en la España de Franco, 1939-1975. Madrid: Consejo Superior de Investigaciones Científicas; 2001, chapter 4, on Antonio Gallego. For the collaboration agreement between Merck and the Banco Urquijo, see Santesmases, 1999, n. 10.

34. Patent number 187371. Other Merck patents submitted: Patent number 187313: A procedure for manufacturing penicillin G salts. Applied for on 04/03/1949 and granted on 23/05/1949. Patent number 187312: A procedure for isolation and purification of penicillin G. Applied for on 04/03/1949; the procedure was interrupted on 31/05/1949 and granted on 08/06/1949. Patent number 187371: A procedure for the production of penicillin. Introduction patent. (American patent number 448790 had been applied for in the USA on 15/05/1943 and granted on 7/08/1948). Applied for on 08/03/1949 and granted on 28/05/1949. Patent number 187378: A procedure for the production of penicillin. (American patent number 43155 had been applied for in the USA on 15/05/1943 and granted on 7/08/1948) AHOEPM, Madrid. 
this company was the only one of the three that also sought to patent a device or instrument: a device for aerating liquids (patent number 194256) ${ }^{35}$.

By introducing their patents - or applying for them - firm applicants showed the strategies to protect their knowledge. The applications also show that the firms were in search of and occupying these virgin markets for penicillin in which production plants could be built. The market for penicillin was huge and US firms and, later on, European firms had been fast in producing this drug ${ }^{36}$.

In August 1949, the Ministry of Industry published its decision to grant two penicillin production plants ${ }^{37}$. The two companies were by then already moving ahead. Each of them had contacted foreign firms for the acquisition of manufacturing rights. In search of the difficult balance between protecting knowledge and opening up new markets, they all had to abide by the procedure required by the Spanish Industrial Protection Law. The accepted proposals were the one submitted by the «Consorcio Químico Español, S.A. and Banco Urquijo S.A.» and the one by «Industria Española de Antibióticos S.A.». «Consorcio Químico Español, S.A. and Banco Urquijo S.A» created the Compañía Española de Penicilinas y Antibióticos (CEPA) in 1949, which acquired Merck's patent to produce penicillin. CEPA built a plant in Madrid, and another one in Aranjuez, a town a few kilometres South of Madrid. The second group whose proposal was accepted was

35. Schenley began four different procedures. It achieved its objective with one of them. Patent number 190142: A method for producing alkaline salts of penicillin. Applied for on 22/10/1949, although there is no record of it having been granted. Patent number 190143: A method for the production of penicillin sodium, applied for on 22/10/1949 and granted on 09/11/1949. Patent number 193056: A method for application of microbiological procedures. Applied for on 15/05/1950, but no record of it being granted exists. Patent number 194256: A device for aerating liquids. Applied for on 22/07/1949 but no record of it being granted exists. AHOEPM, Madrid. Concerns about how to introduce and sterilize the air used in fermentation is already present in the experimental stage in England. Some of the techniques incorporated were those used in alcohol factories. See Hobby, Gladys L. Penicillin. Meeting the challenge. New Haven and London: Yale University Press; 1985, p. 125-140.

36. Hobby, n. 35.

37. Decree of 17 June 1949, which decided the call for proposals published by Decree on 1 September 1948 to manufacture penicillin in Spain in favour of the proposal presented by «Consorcio Químico Español S.A. and Banco Urquijo S.A.» and the proposal presented by «Industria española de antibióticos S.A.». Published in the Boletín Oficial del Estado, 11 August 1949. 
Antibióticos S.A., which acquired Schenley's patent and set up their plant in León, a city in Northwest Spain ${ }^{38}$.

Antibióticos S.A. and CEPA shared the duopoly of penicillin production in Spain ${ }^{39}$. Thus the entry of penicillin patents into Spain also had direct consequences on the regulation of their manufacture: the Spanish State's creation of a duopoly is an indication of the Franco dictatorship's political power over production of the drug. Once again the patent is the link connecting these distinct spaces the government of the dictatorship, medical practitioners and industry- each of them having different interests ${ }^{40}$.

\section{Regulation and the circulation of knowledge}

A patent worked as an agent for making knowledge available. The knowledge included in the patents wording remained invisible in the agreements signed by each part (the US firm and the Spanish one). In them, the detail of the manufacturing procedure was referred to as «submerged culture method»; no further detail was given. On the contrary, patents included every single detail of the manufacturing processes. As patents were public documents, the knowledge American and Danish firms were zealously protecting by patenting was allowed to disseminate. Researchers, and political and health authorities had access to the methods, procedures, instruments and facilities related to the production of penicillin through the patents.

Because products could not be objects of patenting - only procedures could - the three applicant companies, Lovens, Merck and Schenley, had to introduce changes in the wording of the initial applications to modify the headings of the claims so that they related to procedures, and not to products in order to go on with the concession process ${ }^{41}$. Some of the claims were redrafted with more general headings, but others were completely removed from the final draft.

\footnotetext{
38. Santesmases, n. 10, 1999; Puig, n. 19.

39. On the effect of incorporating foreign techniques and technologies on the growth of the Spanish economy from the 1960s onwards, see Cebrián; López, n. 20.

40. On the role of the patent as mediator between the academic, industrial and legislative space, see Gaudillière, n. 5.

41. On the need for regulation created by the production of new techniques/products and their entry into new markets, see: Cassier, n. 6; Simon; Hüntelmann, n. 29.
} 
For example, in the final text of Merck's patent «A procedure to manufacture penicillin G salts» ${ }^{42}$ the ninth item of the claims, initially worded «an alkaline salt of penicillin provided it is prepared according to the procedure indicated in items one through eight» was changed to «a procedure, virtually the same as the one here described». Another example comes from another Merck patent entitled «A procedure for isolation and purification of penicillin $G{ }^{43}$ where, instead of replacing or changing the text, they decided to simply eliminate it: from a total of twenty one claims referring to specific products, in the draft finally approved only seventeen remained.

The initial wording of the applications and the changes introduced as a result of the process deserve a discussion. The initial description of the invention shows the terms and limits the inventor wished to establish, and therefore, what he/she wanted to protect. The final text indicates how the knowledge was to be protected from then on. Thus, regulations determined how the content of patents were expressed, therefore making patents both the object and subject of the processes.

The knowledge about patents became as important as the managerial strategies they suggested. In the applications, it is stated that these same patents were being processed for registration in other countries: the Danish company Lovens, which applied on 23 February 1949 to register the patent entitled «A method to recover a penicillin salt» in Spain, had also applied for its registration in Denmark on 26 February 1948, in Norway on 8 July 1948, in Great Britain on 9 July 1948, in France on 13 July 1948 and in Sweden on 17 July $1948^{44}$.

These strategies - registering the patent in different places over a very short period of time and limiting the areas of influence- were designed and put into practice by the companies themselves. This suggests that the policies adopted by the companies were not isolated policies, but the result of a broader strategy used and supported by the political authorities ${ }^{45}$. If it was politically and economically important for the United States to lead

\footnotetext{
42. Patent number 187313: A procedure to manufacture penicillin G salts. AHOEPM, Madrid.

43. Patent number 187312: A procedure for isolation and purification of penicillin G. AHOEPM, Madrid.

44. Patent number 187178: A method to recover a penicillin salt, Certificate of addition (patent number 184613). AHOEPM, Madrid.

45. Bud, Robert. Penicillin. Triumph and tragedy. Oxford: Oxford University Press; 2007. Tanner, n. 25.
} 
this campaign, it was no less important for the target countries, which saw penicillin production as an incentive to stimulate their industries and as good propaganda for their national policies. The Spanish case is interesting in this respect: a new market was opened up for US firms in which they sold not only penicillin as a product - which already made large profits for the United States firms - but also knowledge, practices, instruments, and the organization necessary to set up a factory to produce it. Moreover, penicillin proved to be a very useful vehicle for the Spanish State to publicise and propagate national industrial and health policies of the dictatorship ${ }^{46}$. Both the US firms and, in this case, the Spanish firms used patents to achieve their aims: the production of penicillin.

The concern and interest of companies was not only to introduce and protect a certain kind of knowledge capable of producing a profit, but also to supervise and control its implementation. Two of the dossiers generated by the applications Merck made to produce penicillin in Spain contain documents that suggest strict control of the use and exploitation of the patent: they are called «start-up certificates». The Merck patent compelled the holder, in this case the representatives of Merck in Spain, to have an official engineer confirm and certify that the use and exploitation of the patent was correct and in accordance with what had been agreed. Certification had to be carried out every year, which suggests that it was more than a simple formality. The law established a period of time for setting up the final exploitation: three years from the date of an invention patent being granted and one for an introduction patent, final exploitation being considered to include the manufacture, sale and use of the object patented. Once the start-up had been accredited, it was necessary to renew the certificate every year in the same way and subject to the same conditions as the start-up.

In the application by patent holders for this quality certificate, once again the idea of controlling the circulation and standardisation of knowledge emerges, now in the manufacturing area. All this indicates that the aim was not only to protect knowledge, but also to protect the product and the interests of the companies that manufactured it. Then the patent has a new function, when added to the source of information, that of technological training. Protection of the product brought with it the use of concrete

46. Santesmases, 2010, n. 10. Capocci in this volume. 
practices that the Spanish technicians had to learn and test in order to obtain the quality certificate. For example, the production of penicillin in submerged conditions needed methods and instruments in order to aerate the solution and maintain a fixed $\mathrm{pH}^{47}$.

Once approved, the patent had to be published in the Boletin Oficial de la Propiedad Industrial, in a large-circulation daily newspaper and in a trade newspaper or industrial journal ${ }^{48}$. The announcements, published as an advertisement, gave the company name, and number and heading of the patent applied for. The requirement of publishing patents granted indicates, on the one hand, the intention of making public knowledge competitive, and also shows that the knowledge concerned could not be put into practice by anyone without permission of the patent property. The law established a period of up to three years, after which, if it had not been licensed, the patent expired.

Patents were treated as public documents, which is implicit - it is established by law - in the actual concept of a patent, and also in their role in the dissemination of knowledge and advertising. For this reason, patents are able to be used as a valid instrument for the study and analysis of knowledge management.

The patents presented here allow us to follow the process and circumstances in which penicillin patents were introduced into Spain. They also permit reflection on the value of the patent as a documentary source. The information found in the patents can be used in many ways, and not for the exclusive use of scientists and technicians. They are administrative documents for a regulatory process, and at the same time they are useful sources for the history of regulatory and manufacturing practices. Administrative processes insist on the production and circulation of knowledge, but the patent documents studied here highlight the fact that they also included information that can determine production, circulation and standardisation processes.

47. Patent number 187312: A procedure for isolation and purification of penicillin G. And patent number 187371: A procedure for the production of penicillin. AHOEPM, Madrid.

48. There are also numerous newspaper cuttings in the dossiers. The dossier with most material of this kind is that of Schenley with the patent number 190143: Method for producing penicillin sodium. AHOEPM, Madrid. 


\section{Conclusions: liability and predictability}

This article highlights the value of patents as a documentary source for the study of the circulation of science and technology. They are good instruments for studying and analysing the management of knowledge and how it circulated in different professional and geographical domains. Knowledge meant, in the case analysed here, both information and training. A degree of consensus was needed for this knowledge to circulate and survive. In this way, patents left the purely bureaucratic space. They were used by industry to produce penicillin and, at the same time, protected the rights of invention.

The procedure for granting patents is a regulatory procedure that ensures quality and guarantees reliability - elements that have played an important role in the development of medicine and medical practice. The regulations, both the present legislation and that of 1929, require that the data and procedures included in the patents enable the innovation for which a patent is sought to be faithfully reproduced, in identical conditions and proportions. Thus patents reveal the components and substances, and also technical details of the production process (temperatures, $\mathrm{pH}$, etc.). This makes the process and the results reliable. Patenting and the obligatory ability to repeat the process ensure, in addition to quality, a guarantee and reliability, another aspect of great value to medicine that is predictability. Control and centralisation of the production process for medicines means, in principle, closer monitoring of the response to and impact from their use an important aspect of public health policy.

Together with the important role patents play in the standardisation, normalisation and control of knowledge, this article shows the importance of these documents in establishing the jurisdiction of both public and private authorities.

Although we have seen that scientific and technological knowledge concerning penicillin travelled in different ways - conferences, articles, agreements - it was patents that conveyed much of that knowledge. The penicillin patent, any of them mentioned here, included additional practices to those of applying and being granted. It was necessary to complete the knowledge contained in the patent with that provided by the technical personnel who travelled to Spain to set up the plants and, later, with the controls established by Spanish law for starting the manufacturing processes. 
Patents gained special prominence as they allowed a network to be created in which political, economic and business, industrial power, public health and international cooperation fields came together. The patent made the regulatory role of the government possible, gave industry the technology it needed, put a new product on the market to be bought and sold, and contributed to medical practice and the curing of infections. Patents were regulators of the relationship among early research at Merck for setting up manufacturing methods to produce penicillin, Spanish firms interested in buying the rights of using those manufacturing methods, and a society composed of doctors and patients who demanded the drug for curing infections. Patents became agents that structured the various interests that evolved around a product.

In Spain there was, most importantly, political will, as well as a space, scientific and academic, industrial and political, in which the knowledge could circulate. The space generated by the law on industrial protection was a decisive element. Patents became a link between the State, industry, and physicians and patients. The resulting administrative procedure paid special attention to the methods of production, standardisation, circulation and introduction onto the market, as well as to the clinical use of these products.

The rapid expansion of penicillin and large-scale production was a response, on one hand, to the therapeutic capacity of the drug, and on the other, to the policies associated with medical demand which arose from the therapeutic capacity of the drug. In this context and faced with growing demand, companies responded to this new situation by entering new markets. The Spanish market appeared, from the documents, to be as attractive as those of its neighbouring countries: patents seeking to enter the Spanish market were, at the same time, also trying to enter other nearby markets. The parallel nature of the practices as well as their coincidence in time suggest that penicillin arrived in Spain at the same time as it did in other European countries. This would not appear to be a coincidence. It seems reasonable to understand this as a result of the strategy of US pharmaceutical firms to occupy virgin geographies so as to fulfill the demand of penicillin in them. There was not any technical deficiency of a country on the socalled periphery, but a trajectory of a drug which was first produced in one country and began to be manufactured in many others. As a result of these expansive strategies of US pharmaceutical firms, the countries in which the firms entered reacted by articulating this phenomenon so as to give it order. 
In the Spanish cases, the controls and regulations of the dictatorship included an emerging pharmaceutical industry and both, the government of the dictatorship and the firms, played a part in relation to public health. Patents came to play a role not only in protecting the knowledge that they themselves helped to standardise and spread, but also in ensuring quality and guaranteeing reliability in the manufacturing, delivery and prescribing of the new drug.

In Spain, penicillin patents started to circulate earlier than any interest by the dictatorship authorities in promoting its manufacturing. It was only later that penicillin was declared by Franco's government as being «of national interest», which meant that the development of the penicillin industry would be supported and protected by the State. It was the Danish company Lovens which introduced its patents in Spain, although the Spanish authorities did not permit the firm to manufacture penicillin in Spain. This reveals one of the strategies used to protect knowledge even before the outcome was known in a country such as Spain, which at that time was not very predictable. The introduction of penicillin into Spain occurred almost ten years before the Stabilisation Plan of 1959, a plan which liberalised the Spanish economy by attracting and promoting foreign investment. In short, this study suggests that in the process of introducing penicillin patents in Spain, practices and processes were set up that called the autarchic system into question.

Apart from the fact that granting penicillin patents in Spain helped to make the drug more widely available, it is worth emphasising the role played by patents in the management and regulation of knowledge: Spanish industry needed the knowledge afforded by US companies. The patent was the legal device used by the authorities of the time to permit the entry of new knowledge and to exploit it without this damaging the interests of those who had previously patented the product and the procedure. The arrival of the penicillin patent in Spain allows us to reflect on the contribution it made to the history of public health and pharmaceutical industry in mid twentieth-century Spain.

\section{Acknowledgements}

I would like to thank Fernando Hernández Izquierdo for his help in accessing the documentation kept in the Historical Archives of the Oficina Española 
de Patentes y Marcas. Comments and suggestions from Emilio Muñoz, Teresa Ortiz and María Jesús Santesmases, together with the anonymous referees for Dynamis, have all helped improve and enrich the content of this article. A preliminary version of this paper was presented at the workshop Circulation of Antibiotics: Journeys of Drugs Standards organized by the ESF Networking program DRUGS. I am grateful to the participants for their comments and suggestions.

Part of the research has been funded by the National Research plan project «Pensamiento científico y experimentación: desarrollo de la instrumentación y las disciplinas biológicas y biomédicas» (HUM200604939/FISO) and by the Intramural Project «Biografía de una patente» (CSIC 2008101002). 